\title{
Prosody-segment Interactions in the Acoustics of Polish Front Vowels*
}

\begin{abstract}
This paper presents an acoustic study devised to investigate the effects of three presumably distinct prosodic position on the phonetic realisation of Polish front vowels in \#CV (that is, following a prosodic boundary and a consonantal onset) and \#VC sequences (that is, immediately following a prosodic boundary). The results of the experiment suggest that Polish does not seem to distinguish between utterance-initial and phrase-initial positions, with some contrasts present between these two positions and phrase-medial tokens with respect to F1. No effects of position have been found for F2 or vowel duration. There are also no clear differences on the acoustic realisation of vowels depending on whether or not they are adjacent to the prosodic boundary. These results raise questions about the nature of prosodic structure in Polish as compared to other languages which show more robust effects.
\end{abstract}

\section{Keywords}

prosody-segment interactions, prosodic hierarchy, segmental phonetics, Polish phonetics, Polish vowels.

\section{Streszczenie}

Artykuł ten przedstawia badanie akustyczne, stworzone, by zbadać efekty trzech różnych pozycji prozodycznych na fonetyczną produkcję przednich samogłosek w języku polskim w sekwencjach \#CV (czyli samogłoski następującej kolejno po granicy prozodycznej

* The author is supported by a grant from the Polish National Science Centre (Narodowe Centrum Nauki), Project Number 2015/19/N/HS2/03395. I am grateful to Geoffrey Schwartz for all his help and support and to Adam Olender for his help with data collection. Thanks also go to two anonymous reviewers. Any remaining errors are my own responsibility. 
i spółgłoskowym nagłosie) oraz \#VC (czyli samogłoski następującej bezpośrednio po granicy prozodycznej). Wyniki eksperymentu sugerują, że jeśli chodzi o F1, język polski wydaje się nie rozróżniać między pozycją początku zdania a początku frazy, podczas gdy pewna liczba różnic została znaleziona między tymi dwoma pozycjami versus pozycją w środku zdania. Różnice nie zostały znalezione, jeśli chodzi o parametr F2 czy długość samogłoski. Nie ma również wyraźnego kontrastu między samogłoskami, które następują bezpośrednio po granicy prozodycznej, a tymi, które od tej granicy dzieli spółgłoska. Wyniki te wskazują na różnice w strukturze prozodycznej języka polskiego w porównaniu z innymi językami, w których znajdujemy bardziej wyraźne efekty.

\section{Słowa kluczowe}

interakcje prozodyczno-segmentalne, hierarchia prozodyczna, fonetyka segmentalna, fonetyka języka polskiego, samogłoski polskie.

\section{Background}

Prosodic strengthening (cf. Cho 2011 for an overview) pertains to strengthening effects observable in segments that occur at the beginning of prosodic domains as postulated by Prosodic Phonology (e.g. Beckman and Pierrehumbert 1986; Nespor and Vogel 1986; Selkirk 1986; Hayes 1989). These prosodic constituents, such as the syllable, the foot, the intonational phrase, and the utterance get progressively bigger and result in the formation of the Prosodic Hierarchy. The variations in the phonetic realisation of segments seem to be related to the strength of the boundary that precedes them - that is, the higher the prosodic level at which they are placed, the stronger the boundary preceding it, and as a corollary, the more prominent the segment that occurs there will be.

As far as phonetic studies that investigate the relationship between the Prosodic Hierarchy and segmental phonetics go, consonants have received decidedly more attention from the scholars and have been well documented. On the acoustic side, VOT remains one of the most widely studied parameters. Consonants seem to either present salient differences with regards to VOT durations depending on the prosodic level at which they are placed (e.g. Fougeron and Keating 1997; Choi 2003 on English; Cho and McQueen 2005 on Dutch; Cho and Jun 2000; Jun 1993 on Korean) or show minimal effects of position (e.g. Fougeron 2001 on French; Kuzla and Ernestus 2011 on German; Wojtkowiak and Schwartz 2019 on Polish). On the articulatory side, consonants at higher prosodic positions have been shown to have, for example, more linguopalatal contact (Fougeron 1991 on French) or higher velum position (Benguerel et al. 1977 on French; Vaissière 1988 on English). However, it is vowels that are of main interest to the present paper and these have been generally rather understudied. The existing data, however, seem to yield support to the hierarchical manner of vocalic strengthening. 
The phonetic studies on the effects of prosodic position on vowels investigate both \#CV sequences - that is, the context where the prosodic boundary is followed by a sequence of a consonant and a vowel, with the consonant adjacent to said boundary, as well as \#VC sequences, where the vowel is placed in an absolute-initial position, and immediately follows the boundary.

Gendrot et al. (2011) studied French and German corpora and found salient effects of position on the acoustic parameters of the vowels in both \#CV sequences and the absolute initial position in both languages, with slightly less influence of the prosodic hierarchy in German. Georgeton and Fougeron (2014) further analysed both spectral and articulatory properties of 10 French vowels in the absolute-initial (i.e. \#VC) position and found that on the whole, at the beginning of an intonational phrase unrounded vowels tend to become even more unrounded, while rounded vowels - more rounded. In this case, it appears that the contrastive feature of a given vowel was enhanced at higher prosodic levels. ${ }^{1}$ Their results, however, were not uniform and the number of speakers included in the analysis was relatively low. Cho and Keating (2001) found no main effect of prosodic position on the duration of vowels in \#CV contexts in Korean. Lee (2007), however, observed more prominent effects of prosodic position on spectral properties of Korean vowels when they were positioned in a \#VC sequence - prosodic strengthening targeted mostly vowel height and at least two prosodic layers were consistently identifiable. While little correlation between height, backness, and duration was found, duration was systematically reduced at the beginning of larger prosodic domains for all vowels but $/ \mathrm{u} /$. Furthermore, an ultrasound study of two non-high vowels, [ $\varepsilon]$ and [0], in American English (Lehnert Le-Houiller et al. 2010) showed greater effects of higher prosodic levels on the articulation in the case of the vowels in absolute-initial (i.e. \#VC) position than those following a consonantal onset (i.e. \#CVC), with very few individual productions distinguishing between intonational phrase and phrase-medial position in the latter context. In turn, Guitard-Ivent et al. (2019) demonstrated that French \#VC sequences placed at the beginning of intonational phrases were more acoustically distinctive and better discriminated using linear discriminant analysis (LDA) and convolutional neural network (CNN) classifications. However, not all vowels were equally affected by prosodically-induced variations, therefore once again highlighting the fact that prosody-segment interactions are by and large voweldependent. Taking all these results into account, it might be the case that the effects of prosody are most prominent, at least as far as the acoustics are concerned, when the vowel is adjacent to the prosodic boundary and does not

${ }^{1}$ Feature Enhancement (Cho and Jun 2000) is in fact one of the theories that make predictions about the nature of prosody-segment interactions, but it is concerned mainly with consonants, and as such, is not described in the present paper. 
follow a consonantal onset. On the other hand, in an EMA study Kim and Cho (2011) found robust effects of prosodic position on /æ/ in English in both \#VC and \#CVC contexts.

In general, when it comes to the effects of position on F1 and F2, when they are present, they seem to depend on a number of factors: not only language, but also the strength of the prosodic boundary preceding the vowel (e.g. Tabain and Perrier 2007 on the differences in F1 and F2 for French /u/ depending on the position), as well as the particular vowel (e.g. Tabain and Perrier 2005 on French; Lee 2007 on Korean), and finally on whether or not the vowel is adjacent to the boundary (Cho and Keating 2001 vs. Lee 2007). Table 1 summarises the main findings of the studies described above.

Table 1. A summary of previous studies on the effects of prosodic position on the acoustics and articulation of vowels across languages ${ }^{2}$

\begin{tabular}{|c|c|c|c|}
\hline Sequence & Language & Effects & Reference \\
\hline \multirow{5}{*}{$\# \mathrm{CV}$} & Korean & $\begin{array}{l}\text { No effects of prosodic position on } \\
\text { duration; }\end{array}$ & Cho and Keating (2001) \\
\hline & English & $\begin{array}{l}\text { EMA study: salient effects of } \\
\text { position in both \#CV and \#VC }\end{array}$ & Kim and Cho (2011) \\
\hline & German & Slight effects of position found; & Gendrot et al. (2011) \\
\hline & French & $\begin{array}{l}\text { Effects of position more robust } \\
\text { than in German; }\end{array}$ & Gendrot et al. (2011) \\
\hline & French & $\begin{array}{l}\text { EMA study: /i/ showed less } \\
\text { robust effects than /a/ }\end{array}$ & $\begin{array}{l}\text { Tabain and Perrier } \\
(2005)\end{array}$ \\
\hline \multirow{4}{*}{ \#VC } & Korean & $\begin{array}{l}\text { Position targets mostly height } \\
\text { (at least two positions distin- } \\
\text { guished); duration reduced after } \\
\text { stronger boundaries (except for } \\
/ \mathrm{u} / \text { ) }\end{array}$ & Lee $(2007)$ \\
\hline & $\begin{array}{l}\text { (American) } \\
\text { English }\end{array}$ & $\begin{array}{l}\text { An ultrasound study: more effects } \\
\text { of position in \#VC sequences. }\end{array}$ & $\begin{array}{l}\text { Lehnert Le-Houiller et al. } \\
(2010)\end{array}$ \\
\hline & French & $\begin{array}{l}\text { Feature enhancement effects } \\
\text { found at the beginning of Intona- } \\
\text { tional Phrase; }\end{array}$ & $\begin{array}{l}\text { Georgeton and Fougeron } \\
(2014)\end{array}$ \\
\hline & French & $\begin{array}{l}\text { Vowels more acoustically } \\
\text { distinctive at the beginning of } \\
\text { Intonational Phrase - easier to } \\
\text { discriminate. }\end{array}$ & $\begin{array}{l}\text { Guitard-Ivent et al. } \\
\text { (2019) }\end{array}$ \\
\hline
\end{tabular}

2 All tables and figures in the text are the author's own work. 
There have been attempts aimed at accounting for the phonetic effects that the Prosodic Hierarchy may exert. The theories which have been proposed, such as Polarisation (Keating 1984), Feature Enhancement (Cho and Jun 2000), or Uniform Strengthening (Cole et al. 2007); however, not only do they appear to make conflicting predictions but they also focus mostly on laryngeal contrasts, without paying attention to vowels.

Conflicting phonetic results raise questions about the phonological validity of the Prosodic Hierarchy as it is traditionally described, particularly with regard to its universality. These phonetic challenges are also accompanied by purely phonological evidence suggesting that prosodic structure is an emergent phenomenon rather than a primitive element of universal grammar (Schiering et al. 2010).

The rest of this paper will proceed as follows. Sections 2 through 4 describe the experimental design and the details of the statistical analysis of the obtained data. Section 5 presents the results of the current study, while Section 6 concludes the paper with some brief discussion of possible phonological implications of the findings.

\section{Materials}

Our project set out to investigate the effects of prosodic position on the phonetic realisation of vowels in both \#VC and \#CV contexts - that is, vowels placed in an absolute-initial position immediately following the prosodic boundary as well as vowels with a consonantal onset adjacent to the prosodic boundary. The study was primarily concerned with the effects of prosodic position on the acoustics of front vowels $[a, \varepsilon, \dot{i}] .{ }^{3}$ While some sources describe /a/ as a low central unrounded vowel, Gussmann (2007: 2) claims it is in fact front, similar in quality to Cardinal Vowel \#4, hence it is included in our dataset. The reason why the remaining Polish vowels, $[\mathrm{i}, \mathrm{u}]$ were excluded from the analysis was the co-articulatory effects that they may have on the preceding consonant. ${ }^{4}$

Therefore, our dataset comprised a list of twenty four disyllabic Polish words, starting with /p, t, k, b, d, g/, which were followed by three front vow-

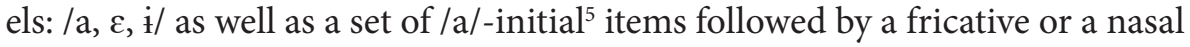

3 The back vowel [0] was excluded as the proximity of $\mathrm{F} 1$ and $f_{0}$ prevented us from obtaining reliable F1 measurements (Bark-normalised, F1- $f_{0}$; Syrdal and Gopal 1986).

${ }^{4}$ Both of these high vowels might influence the VOT duration (Weismer 1979) and studying that consonantal parameter was an important part of the present project, which constitutes the reason for not including keywords with these vowels in our data set.

${ }^{5}$ A reviewer notes that while there are no [i]-initial words in Polish, there are many nativised $[\varepsilon]$-initial words and wonders why those were not included in our dataset. The reason for that is that the idea to study \#VC sequences appeared after the data had already been collected. 
consonant (six keywords in total). It is important to note that the vowel $/ \mathrm{i} /$ is subject to some distributional restrictions in Polish and does not occur after velar plosives. As far as the voiceless series is concerned, in the original dataset in this context the vowel $\langle e ̨>$, realised as $[\varepsilon \tilde{\mathrm{w}}]$ was chosen (the word was

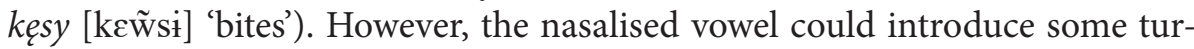
moil to the obtained results, as the realisation of nasalised vowels in Polish can vary, and as such this target word was completely excluded from the analysis. In the case of the voiced velar, we used the word gyros ([giros], 'gyros'), which is not a native Polish word but with which Polish speakers are familiar due to its ubiquity. Therefore, it was not excluded.

These target words were embedded in meaningful sentences, carefully controlled for the number of syllables that preceded and followed them. The sentences were devised in a way for the target words to be placed at three distinct prosodic positions: utterance-initial, phrase-initial (i.e. utterance-medial), and phrase-medial. The study was modelled on Kuzla and Ernestus' (2011) design.

The first prosodic position of interest, the utterance-initial one, denotes a position wherein the target word is preceded by a robust prosodic break, indicated by a full stop in the spelling. The second position, i.e. phrase-initial, places the target word at the beginning of a perceptually salient phrase, which Shattuck-Hufnagel and Turk (1996: 210-2011) describe as an intonational phrase. Therein, the target word is preceded by a weaker prosodic break, which is represented as a comma in orthography. Finally, the third position of interest, i.e. phrase-medial, entails no salient prosodic breaks preceding the target word. Kuzla and Ernestus (2011) stress the importance of differentiating between domain-initial strengthening effects and the effects of phrasal accentuation. In order to control for that, the target words were placed in two distinct accentual conditions: accented, in which pitch accent was supposed to be put on the actual target word and unaccented, in which pitch accent would fall on the item following the target word. The dataset is illustrated in (1) with the target word tyfus 'typhus' (the target word is underlined, the accented item is bolded).

1. a) Dziś skutecznie go leczymy. Tyfus został już opanowany. Nowadays we successfully treat it. Typhus has been contained. Sentence type: Utterance-initial, accented.

b) Dziś skutecznie go leczymy. Tyfus został już opanowany. Nowadays we successfully treat it. Typhus has been contained. Sentence type: Utterance-initial, unaccented.

As a result, this small subset of [a]-initial words was all the authors had at their disposal. Including more vowels in the study might be an interesting avenue for future considerations. 
c) Choć skutecznie go leczymy, tyfus nadal budzi przerażenie. Although we can successfully treat it, typhus still evokes fear. Sentence type: Phrase-initial, accented.

d) Choć skutecznie go leczymy, tyfus nadal budzi przerażenie. Although we can successfully treat it, typhus still evokes fear. Sentence type: Phrase-initial, unaccented.

e) W dzisiejszych czasach leczymy tyfus dzięki antybiotykowi. Nowadays we treat typhus with antibiotics.

Sentence type: Phrase-medial, accented.

f) W dzisiejszych czasach leczymy tyfus dzięki antybiotykowi. Nowadays we treat typhus with antibiotics.

Sentence type: Phrase-medial, unaccented.

In total, the dataset consisted of 144 sentences (i.e. six - three voiceless, three voiced - plosives, three vowels, two accentual conditions, three prosodic positions + six /a/-initial items in two accentual conditions, three prosodic positions). We also included a number of filler sentences, with fricative-, affricate-, and cluster-initial target words, whose internal structure mirrored this of the sentences described above. As a result, 299 sentences were elicited from each of our participants.

\section{Procedure}

Twenty monolingual native speakers of Polish (fourteen females and six males) took part in our experiments. Although they claimed not to be fluent in any other foreign language, they had history of studying other languages - such as English and German - at school. However, they had never undergone any specialised phonetic training. The participants were aged 18-29 (median age: 24) and were paid for their participation in the study. They reported no hearing or speech impairments.

The recordings were made at a Polish university. The dataset was randomised for each participant, with the item on which the pitch accent was supposed to fall bolded. The sentences were presented to the participants on PowerPoint slides, on a monitor housed inside a soundproof recording booth, which was also equipped with a high quality microphone and USB audio interfaces that allow for recording directly onto the computer. 


\section{Acoustic and statistical analyses}

To ensure that the participants produced sentences in accord with the prosodic boundary that a given sentence was supposed to illustrate, as well as that the sentence accent fell on the correct syllable, two native Polish speakers trained in phonetics and acoustic annotations independently listened to the recordings (fully crossed design, Hallgren 2012) and marked them as correct (i.e. the speaker produced the sentence they were supposed to, with regards to both prosodic position and accentual condition) or incorrect (i.e. the speaker did not produce the expected prosodic boundary and/or the desired accentual variant). The Cohen's Kappa Coefficient (Cohen 1968) agreement between the raters was calculated and the results showed that agreement regarding both accentual condition and prosodic position were 'almost perfect' ( $\mathrm{k}=0.97$, following Landis and Koch 1977). The tokens which yielded disagreement between the two raters, with respect to either factor (i.e. prosodic position and/or accentual condition) were discarded. The excluded sentences were also those wherein the sentences were produced with errors, unnatural production of the prosodic boundary or accentedness, or hesitations. As a result, out of 2880 sentences produced, 2631 were included in the proper acoustic analysis.

The acoustic annotation was done manually in Praat (Boersma and Weenink 2019). As far as vowels are concerned, the duration was measured from the end of the release noise of the preceding consonant and subsequent onset of voicing until the point in which F2 and F3 were no longer visible. Release noise was not treated as part of the vowel. We also marked the duration of the entire sentence to be able to then calculate the speech rate.

In the case of \#VC sequences, the presence or absence of a glottal stop was also taken into consideration. Glottal-marking of word-initial vowels of Polish has been widely described (e.g. Dukiewicz and Sawicka 1995; Gussmann 2007; Schwartz 2012, 2013; Malisz et al. 2013) and the insertion of the glottal stop is often seen as a repair strategy for the preference for consonantal onsets, functioning as a filler of an empty onset (Gussmann 2007: 24). Additionally, Brunner and Żygis (2011) provide evidence that cross-linguistically the co-occurrence of glottal stops and low vowel is especially common, therefore given that our keywords began with a low front vowel /a/, glottal insertion was all the more expected.

The reason why we decided to spilt \#VC sequences into glottalised and not glottalised was to see whether vowels in the latter category would show more robust effects of prosodic position, as not only would they be placed in the absolute-initial position, but they would also immediately follow the boundary. In the case of glottalised vowels, we could expect less salient effects as the prosodic boundary and vowel would have a glottal stop occurring in-between them, making them "less" adjacent as a result, as theorised Cho and Keating 
(2009), whose work suggests that domain boundary effects tend to be local to the boundary-adjacent segment. The presence or absence of a glottal stop was marked in a binary way (yes or no). The acoustic correlates that were taken into account were visible effects of creakiness on the vowel and drops in $f_{0}$ (e.g. Pompino-Marschall and Żygis 2011; Przedlacka and Ashby 2011), or a presence of a full glottal stop (Redi and Shattuck-Hufnagel 2001). As far as segmentation is concerned, full glottal stops were excluded from the analysed vowel; creakiness, in turn, was treated as part of the vowel, as upon visual inspection, no robust effects of creakiness on the formants were observable.

The acoustic measurements were subsequently extracted using Praat scripts. The mean duration measures were obtained in milliseconds. Then, we also extracted mean F1 and F2 (Bark normalised, F1- $f_{0}$ and F3-F2 respectively, cf. Syrdal and Gopal 1986) ${ }^{6}$ over the entire duration of the vowel. Speech rate for each sentence was calculated (the duration of the entire utterance divided by the number of syllables). Statistical analyses were done in the SPSS software (IBM Corporation 2017). Generalised Linear Mixed Models were run with the following dependent variables: F1 $\left(\mathrm{F} 1-f_{0}\right)$ and F2 (F3-F2) as well as vowel duration. Speaker and Item were random factors, while (Prosodic) Position ${ }^{\star}$ Vowel $^{\star}$ Accent and Speech Rate were fixed factors. Since the dataset was counterbalanced for voicing, the laryngeal contrast in onsets was excluded from the model. In the case of \#VC sequences, glottalisation was an additional fixed factor. A detailed description of the results of these analyses follows in Section 5.

\section{Results}

\subsection{F1}

This subsection describes the results of the analyses with F1 as the dependent variable.

\subsection{1. \#CV SEQUENCES}

Mean F1 values (Bark normalised, F1- $f_{0}$ over the entire duration of the vowel) to measure vowel height were obtained for each of the three vowels. In total, 1950 tokens were analysed, out of which 973 were accented and 977 unaccented. In what follows, we will discuss each vowel individually.

\footnotetext{
${ }^{6}$ The Bark-difference measures used in the Syrdal and Gopal normalization method have been found to better reflect the auditory properties of phonological categories associated with vowels, such as height and backness, than raw values of single formants (see Chistovich and Lublinskaya 1979; Hoemeke and Diehl 1994). While Syrdal and Gopal's normalisation has been found to be slightly less successful than vowel-extrinsic methods in classification studies dealing with sociolinguistic variation, the present study does not focus on language variation or speech categorisation.
} 
Beginning with [i], 572 realisations of this vowel were analysed, out of which 189 were utterance-initial, 189 phrase-initial, and 194 phrase-medial. ${ }^{7}$ Recall that this particular vowel's subset was smaller in number, since the sequence [ $\left.{ }^{*} \mathrm{ki}\right]$ was missing. In general, F1 was lower in the accented condition (Mean $=2.19, \mathrm{SD}=.56)$ than in the unaccented condition $($ Mean $=2.24$, $\mathrm{SD}=.47)$, however the difference was not significant $(\mathrm{t}=1.238, \mathrm{p}=.216)$. This is summarised in Table 2.

Table 2. Mean F1 values (in Bark, F1- $f_{0}$ ) of the vowel [i] in the \#CV sequence, sorted for accentedness and prosodic position

\begin{tabular}{|c|c|c|c|c|}
\hline \multicolumn{1}{|c|}{ Accent } & Position & No. of cases & Mean & Std. Dev. \\
\hline \multirow{3}{*}{ Accented } & U-I & 94 & 2.10 & .61 \\
\cline { 2 - 5 } & P-I & 97 & 2.19 & .56 \\
\cline { 2 - 5 } & P-M & 96 & 2.30 & .50 \\
\hline \multirow{3}{*}{ Unaccented } & U-I & 95 & 2.14 & .41 \\
\cline { 2 - 5 } & P-I & 92 & 2.18 & .45 \\
\cline { 2 - 5 } & P-M & 98 & 2.39 & .50 \\
\hline
\end{tabular}

Significant effects of position could be found in both accentual conditions. Within the accented vowels, contrast was observed between utterance-initial and phrase-medial tokens $(\mathrm{p}=.002)$. In the unaccented condition, there were differences between phrase-initials and phrase-medials $(p=.002)$ as well as between utterance-initials and phrase-medials $(\mathrm{p}<.001)$. No difference was observed between utterance-initial and phrase-initial tokens. These results are shown in Table 3, with significant contrasts bolded.

Table 3. The summary of the Generalised Mixed Model analysis of the effects of position on the F1 (in Bark, F1- $f_{0}$ ) of the vowel [i] in the \#CV sequence (pairwise comparisons)

\begin{tabular}{|c|c|c|c|c|c|}
\hline Accent & Position & Contrast estimate & Std. Error & $\mathbf{t}$ & Sig. \\
\hline \multirow{3}{*}{ Accented } & U-I vs. P-I & .078 & .065 & 1.194 & .233 \\
\cline { 2 - 6 } & U-I vs. P-M & .204 & .065 & $\mathbf{3 . 1 1 5}$ & $\mathbf{. 0 0 2}$ \\
\cline { 2 - 6 } & P-I vs. P-M & .126 & .065 & 1.939 & .053 \\
\hline \multirow{3}{*}{ Unaccented } & U-I vs. P-I & .070 & .066 & 1.062 & .288 \\
\cline { 2 - 7 } & U-I vs. P-M & $\mathbf{. 2 7 0}$ & $\mathbf{. 0 6 5}$ & $\mathbf{4 . 1 6 0}$ & $<.001$ \\
\cline { 2 - 7 } & P-I vs. P-M & $\mathbf{. 2 0 0}$ & $\mathbf{. 0 6 5}$ & $\mathbf{3 . 0 5 6}$ & $\mathbf{. 0 0 2}$ \\
\hline
\end{tabular}

${ }^{7}$ For the sake of clarity of the tables which detail the results, the names of the three prosodic positions of interest have been abbreviated throughout the paper. Hence, the utterance-initial position will be referred to as "U-I", the phrase-initial one as "P-I", while the phrase-medial one as "P-M" from this point forward. 
When it comes to $[\varepsilon], 693$ items were considered: 228 utterance-initial ones, 228 phrase-initial ones, and 237 phrase-medial ones. F1 was once again higher in accented $($ Mean $=3.46, \mathrm{SD}=.63)$ than unaccented $($ Mean $=3.19, \mathrm{SD}=.63)$ tokens and the contrast was significant $(t=8.362, \mathrm{p}=<.001)$. Mean values for both conditions and each position are given in Table 4.

Table 4. Mean F1 values (in Bark, F1- $f_{0}$ ) of the vowel $[\varepsilon]$ in the \#CV sequence, sorted for accentedness and prosodic position

\begin{tabular}{|c|c|c|c|c|}
\hline \multicolumn{1}{|c|}{ Accent } & Position & No. of cases & Mean & Std. Dev. \\
\hline \multirow{3}{*}{ Accented } & U-I & 114 & 3.35 & .63 \\
\cline { 2 - 5 } & P-I & 111 & 3.38 & .66 \\
\cline { 2 - 5 } & P-M & 119 & 3.65 & .56 \\
\hline \multirow{3}{*}{ Unaccented } & U-I & 114 & 3.16 & .63 \\
\cline { 2 - 5 } & P-I & 117 & 3.13 & .65 \\
\cline { 2 - 5 } & P-M & 118 & 3.27 & .60 \\
\hline
\end{tabular}

Effects of position were observable in both conditions. In the accented items, statistical significance was reached between phrase-initial and phrase-medial items $(\mathrm{p}<.001)$ as well as between utterance-initial and phrase-medial ones $(\mathrm{p}<.001)$. These effects were mirrored in the unaccented condition: contrast was found between phrase-initials and phrase-medials $(\mathrm{p}=.016)$ and utterance-initials and phrase-medials $(\mathrm{p}=.042)$. No difference was observed between phrase-initials and utterance-initials in both conditions. The results are summarised in Table 5. Significant contrasts are bolded.

Table 5. The summary of the Generalised Mixed Model analysis of the effects of position on the F1 (in Bark, F1- $f_{0}$ ) of the vowel $[\varepsilon]$ in the \#CV sequence (pairwise comparisons)

\begin{tabular}{|c|l|c|c|c|c|}
\hline \multirow{1}{*}{ Accent } & \multicolumn{1}{|c|}{ Position } & Contrast estimate & Std. Error & $\mathbf{t}$ & Sig. \\
\hline \multirow{3}{*}{ Accented } & U-I vs. P-I & .033 & .060 & .546 & .585 \\
\cline { 2 - 6 } & U-I vs. P-M & .296 & .059 & $\mathbf{5 . 0 1 4}$ & $<.001$ \\
\cline { 2 - 6 } & P-I vs. P-M & .263 & .059 & $\mathbf{4 . 4 3 0}$ & $<.001$ \\
\hline \multirow{3}{*}{ Unaccented } & U-I vs. P-I & .021 & .059 & .347 & .729 \\
\cline { 2 - 7 } & U-I vs. P-M & .121 & $\mathbf{. 0 5 9}$ & $\mathbf{2 . 0 3 8}$ & $\mathbf{. 0 4 2}$ \\
\cline { 2 - 7 } & p-I vs. P-M & $\mathbf{. 1 4 1}$ & $\mathbf{. 0 5 9}$ & $\mathbf{2 . 4 0 2}$ & $\mathbf{. 0 1 6}$ \\
\hline
\end{tabular}

Finally, as far as the vowel [a] is concerned, we looked at 689 tokens: 228 in the utterance-initial position, 231 in the phrase-initial position, and 230 in the phrase-medial position. In general, F1 was higher in the accented condition (Mean $=4.69, \mathrm{SD}=.69$ vs. Mean $=4.29, \mathrm{SD}=.67$ respectively) and the contrast 
was significant $(\mathrm{t}=11.539, \mathrm{p}=.000)$. Mean values of $\mathrm{F} 1 \mathrm{for}$ each condition and position are given in Table 6.

Table 6. Mean F1 values (in Bark, F1- $f_{0}$ ) of the vowel [a] in the \#CV sequence, sorted for accentedness and prosodic position

\begin{tabular}{|c|c|c|c|c|}
\hline \multirow{1}{*}{ Accent } & Position & No. of cases & Mean & Std. Dev. \\
\hline \multirow{4}{*}{ Accented } & U-I & 113 & 4.67 & .63 \\
\cline { 2 - 5 } & P-I & 118 & 4.60 & .66 \\
\cline { 2 - 5 } & P-M & 113 & 4.88 & .62 \\
\hline \multirow{3}{*}{ Unaccented } & U-I & 115 & 4.29 & .67 \\
\cline { 2 - 5 } & P-I & 113 & 4.26 & .74 \\
\cline { 2 - 5 } & P-M & 117 & 4.31 & .62 \\
\hline
\end{tabular}

Effects of prosodic position on F1 of the vowel [a] were significant only in the accented condition and only between two positions. Pairwise comparisons showed that there were significant contrasts between phrase-initial and phrase-medial items $(\mathrm{p}=.002)$. A detailed summary of the analysis is shown in Table 7, with the one significant contrast in bold.

Table 7. The summary of the Generalised Mixed Model analysis of the effects of position on the F1 (in Bark, F1- $f_{0}$ ) of the vowel [a] in the \#CV sequence (pairwise comparisons)

\begin{tabular}{|c|c|c|c|c|c|}
\hline Accent & Position & Contrast estimate & Std. Error & $\mathbf{t}$ & Sig. \\
\hline \multirow{3}{*}{ Accented } & U-I vs. P-I & .066 & .060 & 1.116 & .265 \\
\cline { 2 - 6 } & U-I vs. P-M & .117 & .060 & 1.948 & .052 \\
\cline { 2 - 6 } & P-I vs. P-M &. $\mathbf{1 8 3}$ & $\mathbf{. 0 5 9}$ & $\mathbf{3 . 0 8 7}$ & $\mathbf{. 0 0 2}$ \\
\hline \multirow{3}{*}{ Unaccented } & U-I vs. P-I & .049 & .060 & .818 & .414 \\
\cline { 2 - 6 } & U-I vs. P-M & $<.001$ & .059 & .000 & 1.000 \\
\cline { 2 - 6 } & P-I vs. P-M & .049 & .060 & .823 & .411 \\
\hline
\end{tabular}

The results of the analyses of the effects of prosodic position on the F1 $\left(\mathrm{F} 1-f_{0}\right)$ in \#CV sequences for all three vowels are visualised in Figure 1. 


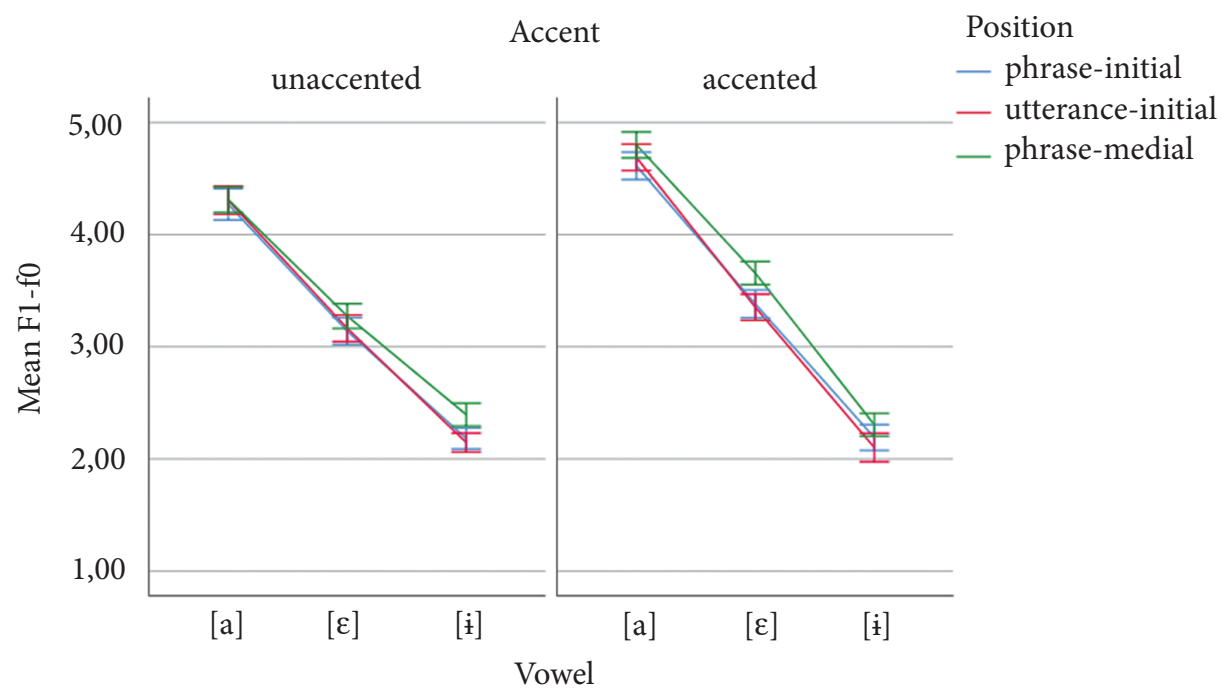

Error bars: $95 \% \mathrm{Cl}$

Figure 1. Comparison of F1 values $\left(\mathrm{F} 1-f_{0}\right)$ sorted for position, accentedness, and the vowel

\subsection{2. \#VC SEQUENCES}

Similarly to the vowels following a consonantal onset, F1 measurements (mean F1 $f_{0}$, Bark normalised, over the entire duration of the vowel) were obtained for the vowel [a] in the absolute-initial position. In total, 681 tokens were analysed, out of which 347 were accented and 334 unaccented. On average, F1 was higher in the accented condition $(\mathrm{t}=3.306, \mathrm{p}=.001)$; phrase-medial tokens in either conditions yielded the highest values. Table 8 illustrates mean F1 for each prosodic position in either of the accentual conditions.

Table 8. Mean F1 values (in Bark, F1- $f_{0}$ ) of the vowel [a] in the \#VC sequence, sorted for accentedness and prosodic position

\begin{tabular}{|c|c|c|c|c|}
\hline \multirow{1}{*}{ Accent } & Position & No. of cases & Mean & Std. Dev. \\
\hline \multirow{4}{*}{ Accented } & U-I & 118 & 5.14 & .65 \\
\cline { 2 - 5 } & P-I & 116 & 5.16 & .71 \\
\cline { 2 - 5 } & P-M & 113 & 5.41 & .72 \\
\hline \multirow{3}{*}{ Unaccented } & U-I & 108 & 4.99 & .91 \\
\cline { 2 - 5 } & P-I & 109 & 5.00 & .74 \\
\cline { 2 - 5 } & P-M & 117 & 5.09 & .67 \\
\hline
\end{tabular}

In general, F1 was also higher in \#VC sequences, which entails vowel lowering, than in \#CV sequences (i.e. where [a] was preceded by a consonant; other vowel contexts were excluded from this comparison) and this contrast 
was significant for every position in both accented and unaccented tokens $(\mathrm{p}<.001)$. This is to be expected, as consonants have been shown to affect the formant values of vowels (cf. Stevens and House 1963). These differences are shown in Figure 2.

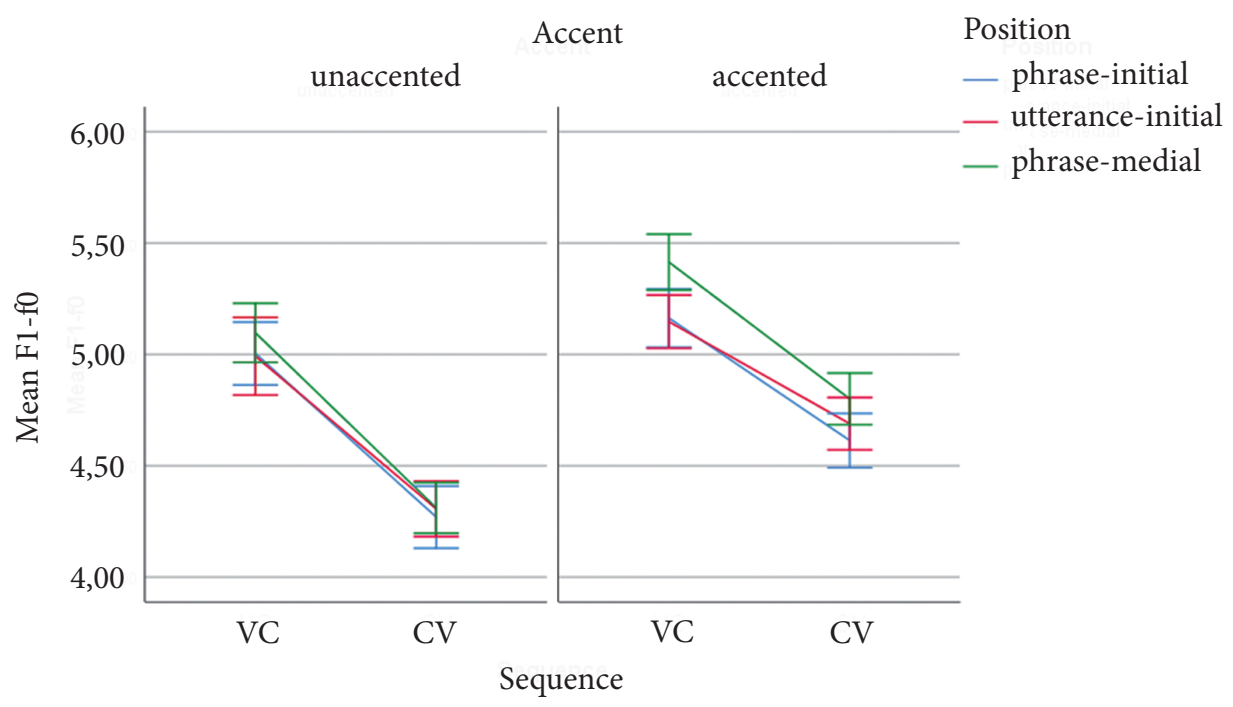

Figure 2. Comparisons of F1 values (in Bark, F1- $f_{0}$ ) of the vowel [a] between the two sequences (\#VC vs. \#CV), sorted for accentedness and prosodic position

As has been mentioned in Section 4, the predictors of the statistical model included the interactions between the Prosodic Position ${ }^{\star}$ Accent ${ }^{\star}$ Glottalisation, with speech rate as an additional predictor and with Speaker and Item as random factors. Out of 681 items included in the analysis, 438 vowels were either preceded by a full glottal stop or with visible glottalisation effects, and 243 were not glottalised. However, an additional Binary Logistic Regression analysis with glottalisation as the dependent variable did not reveal any of the prosodic positions to be more likely to yield a glottalised production, nor any accentual condition to be more susceptible to this process.

Subsequently, in a Generalised Linear Mixed Models analysis, the effects of position did not reach statistical significance, either in the case of glottalised or not glottalised items. Table 9 summarises these findings. 
Table 9. The summary of the Generalised Mixed Model analysis of the effects of position on the F1 (in Bark, F1- $f_{0}$ ) of the vowel [a] in the \#VC sequence (pairwise comparisons)

\begin{tabular}{|c|c|c|c|c|c|c|}
\hline Glottalisation & Accent & Position & Contrast estimate & Std. Error & $\mathbf{t}$ & Sig. \\
\hline \multirow{6}{*}{ 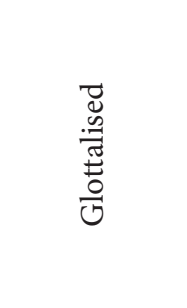 } & \multirow[t]{3}{*}{ accented } & U-I vs. P-I & .125 & .155 & .804 & .422 \\
\hline & & U-I vs. P-M & .301 & .156 & 1.935 & .053 \\
\hline & & P-I vs. P-M & .177 & .153 & 1.156 & .248 \\
\hline & \multirow[t]{3}{*}{ unaccented } & U-I vs. P-I & .015 & .156 & .097 & .923 \\
\hline & & U-I vs. P-M & .077 & .153 & .502 & .616 \\
\hline & & P-I vs. P-M & .092 & .153 & .601 & .548 \\
\hline \multirow{6}{*}{ 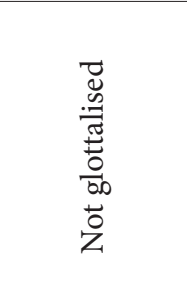 } & \multirow[t]{3}{*}{ accented } & U-I vs. P-I & .104 & .166 & .628 & .530 \\
\hline & & U-I vs. P-M & .168 & .167 & 1.006 & .315 \\
\hline & & P-I vs. P-M & .272 & .168 & 1.615 & .107 \\
\hline & \multirow[t]{3}{*}{ unaccented } & U-I vs. P-I & .021 & .175 & .123 & .902 \\
\hline & & U-I vs. P-M & .068 & .201 & .337 & .463 \\
\hline & & P-I vs. P-M & .046 & .204 & .227 & .821 \\
\hline
\end{tabular}

\subsection{F2}

Having looked at F1, we now can move on to discussing the second formant, again in the case of \#CV and \# $\mathrm{VC}$ sequences.

\subsection{1. \#CV SEQUENCES}

For F2, mean values (Bark normalised, F3-F2 over the entire duration of the vowel) were gathered for each vowel. Once again, 1950 items were analysed, out of which 973 were accented and 977 were unaccented. Now we will consider the effects of prosodic position on F2 for each vowel.

The first vowel analysed, [i] , yielded 572 tokens: 189 in the utterance-initial position, 189 in the phrase-initial position, and 194 in the phrase-medial position. On average, F2 of this vowel was lower in the accented condition (Mean $=2.47, \mathrm{SD}=.52)$ than in the unaccented one $($ Mean $=2.77, \mathrm{SD}=.69)$ and the contrast was significant $(\mathrm{t}=6.750, \mathrm{p}=<.001)$. The means are summarised in Table 10. 
Table 10. Mean F2 values (in Bark, F3-F2) of the vowel [i] in the \#CV sequence, sorted for accentedness and prosodic position

\begin{tabular}{|c|c|c|c|c|}
\hline \multicolumn{1}{|c|}{ Accent } & Position & No. of cases & Mean & Std. Dev. \\
\hline \multirow{3}{*}{ Accented } & U-I & 94 & 2.54 & .49 \\
\cline { 2 - 5 } & P-I & 97 & 2.49 & .55 \\
\cline { 2 - 5 } & P-M & 96 & 2.40 & .52 \\
\hline \multirow{3}{*}{ Unaccented } & U-I & 95 & 2.76 & .61 \\
\cline { 2 - 5 } & P-I & 92 & 2.72 & .69 \\
\cline { 2 - 5 } & P-M & 98 & 2.82 & .78 \\
\hline
\end{tabular}

The statistical analysis revealed that no significant effects of position were found, which can be seen in Table 11 .

Table 11. The summary of the Generalised Mixed Model analysis of the effects of position on the F2 (in Bark, F3-F2) of the vowel [i] in the \#CV sequence (pairwise comparisons)

\begin{tabular}{|c|c|c|c|c|c|}
\hline Accent & Position & Contrast estimate & Std. Error & $\mathbf{t}$ & Sig. \\
\hline \multirow{3}{*}{ Accented } & U-I vs. P-I & .032 & .077 & .412 & .680 \\
\cline { 2 - 6 } & U-I vs. P-M & .128 & .077 & 1.646 & .100 \\
\cline { 2 - 6 } & P-I vs. P-M & .096 & .077 & 1.245 & .213 \\
\hline \multirow{3}{*}{ Unaccented } & U-I vs. P-I & .048 & .078 & .618 & .536 \\
\cline { 2 - 6 } & U-I vs. P-M & .034 & .077 & .436 & .663 \\
\cline { 2 - 6 } & P-I vs. P-M & .082 & .078 & 1.056 & .234 \\
\hline
\end{tabular}

In the case of the second vowel, [ $[$ ], we looked at 693 tokens, out of which 228 were utterance-initial, 231 phrase-initial, and 237 phrase-medial. Here, in general F2 was lower in the accented condition compared to the unaccented condition (Mean $=2.65, \mathrm{SD}=.55$ vs. Mean $=2.87, \mathrm{SD}=.69$ respectively) and the difference was significant $(t=5.473, \mathrm{p}=<.001)$. Table 12 showcases these results.

Table 12. Mean F2 values (in Bark, F3-F2) of the vowel [ $\varepsilon$ ] in the \#CV sequence, sorted for accentedness and prosodic position

\begin{tabular}{|c|c|c|c|c|}
\hline Accent & Position & No. of cases & Mean & Std. Dev. \\
\hline \multirow{3}{*}{ Accented } & U-I & 113 & 3.83 & .79 \\
\cline { 2 - 5 } & P-I & 118 & 3.84 & .80 \\
\cline { 2 - 5 } & P-M & 113 & 3.84 & .82 \\
\hline \multirow{3}{*}{ Unaccented } & U-I & 115 & 3.75 & .87 \\
\cline { 2 - 5 } & P-I & 113 & 3.69 & .82 \\
\cline { 2 - 5 } & P-M & 117 & 3.74 & .90 \\
\hline
\end{tabular}


Similarly to $[\dot{i}]$, no significant effects of position were observed for the vowel [ع]. The details are given in Table 13 .

Table 13. The summary of the Generalised Mixed Model analysis of the effects of position on the F2 (in Bark, F3-F2) of the vowel $[\varepsilon]$ in the \#CV sequence (pairwise comparisons)

\begin{tabular}{|c|c|c|c|c|c|}
\hline Accent & Position & Contrast estimate & Std. Error & $\mathbf{t}$ & Sig. \\
\hline \multirow{3}{*}{ Accented } & U-I vs. P-I & .040 & .071 & .568 & .570 \\
\cline { 2 - 6 } & U-I vs. P-M & .032 & .070 & .454 & .650 \\
\cline { 2 - 6 } & P-I vs. P-M & .009 & .070 & .123 & .902 \\
\hline \multirow{3}{*}{ Unaccented } & U-I vs. P-I & .022 & .070 & .315 & .753 \\
\cline { 2 - 6 } & U-I vs. P-M & .046 & .070 & .654 & .513 \\
\cline { 2 - 6 } & P-I vs. P-M & .068 & .070 & .977 & .329 \\
\hline
\end{tabular}

As far as [a] is concerned, 689 instances were considered: 228 utterance-initials, 231 phrase-initials, and 230 phrase-medials. On average, F2 was higher in the accented condition (Mean $=3.84, \mathrm{SD}=.80$ ) than the unaccented condition (Mean $=3.73, \mathrm{SD}=.86)$ and the contrast was, once again, significant $(\mathrm{t}=2.512$, $\mathrm{p}=.012$ ). The means are shown in Table 14 .

Table 14. Mean F2 values (in Bark, F3-F2) of the vowel [a] in the \#CV sequence, sorted for accentedness and prosodic position

\begin{tabular}{|c|c|c|c|c|}
\hline \multicolumn{1}{|c|}{ Accent } & Position & No. of cases & Mean & Std. Dev. \\
\hline \multirow{3}{*}{ Accented } & U-I & 113 & 3.83 & .79 \\
\cline { 2 - 5 } & P-I & 118 & 3.84 & .80 \\
\cline { 2 - 5 } & P-M & 113 & 3.84 & .82 \\
\hline \multirow{3}{*}{ Unaccented } & U-I & 115 & 3.75 & .87 \\
\cline { 2 - 5 } & P-I & 113 & 3.69 & .82 \\
\cline { 2 - 5 } & P-M & 117 & 3.74 & .90 \\
\hline
\end{tabular}

Further statistical analysis revealed that no contrasts between positions in either of the accentual conditions reached significance. Table 15 illustrates details thereof. 
Table 15. The summary of the Generalised Mixed Model analysis of the effects of position on the F2 (in Bark, F3-F2) of the vowel [a] in the \#CV sequence (pairwise comparisons)

\begin{tabular}{|c|c|c|c|c|c|}
\hline Accent & Position & Contrast estimate & Std. Error & $\mathbf{t}$ & Sig. \\
\hline \multirow{3}{*}{ Accented } & U-I vs. P-I & .030 & .071 & .423 & .673 \\
\cline { 2 - 6 } & U-I vs. P-M & .033 & .071 & .464 & .643 \\
\cline { 2 - 6 } & P-I vs. P-M & .003 & .070 & .046 & .964 \\
\hline \multirow{3}{*}{ Unaccented } & U-I vs. P-I & .036 & .071 & .508 & .612 \\
\cline { 2 - 6 } & U-I vs. P-M & .014 & .070 & .193 & .847 \\
\cline { 2 - 6 } & P-I vs. P-M & .050 & .071 & .704 & .482 \\
\hline
\end{tabular}

Figure 3 illustrates the analysis of the effects of prosodic position on F2 (F3-F2) of the three vowels.

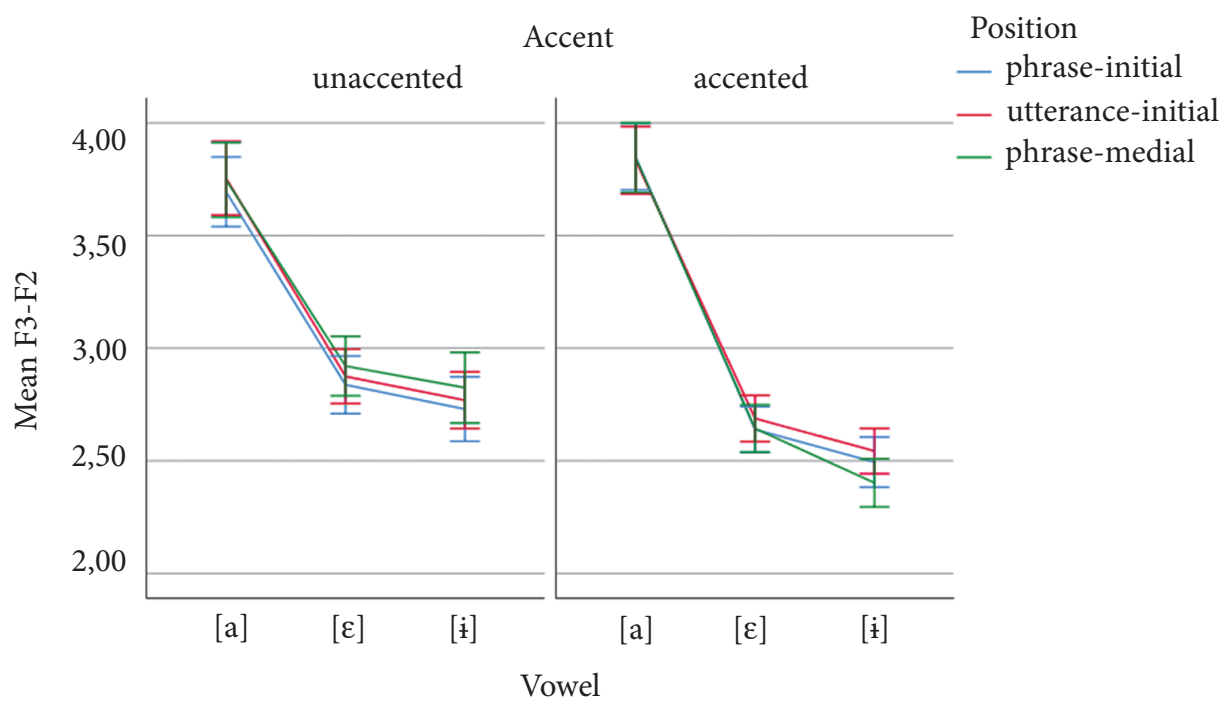

Error bars: $95 \% \mathrm{Cl}$

Figure 3. Comparison of the F2 values (in Bark, F3-F2) in the \#CV sequences, sorted for accentedness, prosodic position, and the vowel

\subsection{2. \#VC SEQUENCES}

As was the case with \#CV sequences, F2 measurements (mean F3-F2, Bark normalised, over the entire duration of the vowel) were obtained for the vowel [a] in the absolute-initial position. Once again, 681 tokens were analysed, out of which 347 were accented and 334 unaccented. By and large, the differences in F2 were relatively small, which is shown in Table 16 and the contrast between accentual conditions was not significant $(\mathrm{t}=1.558, \mathrm{p}=.120)$. 
Table 16. Mean F2 values (in Bark, F3-F2) of the vowel [a] in the \#VC sequence, sorted for accentedness and prosodic position

\begin{tabular}{|c|c|c|c|c|}
\hline Accent & Position & No. of cases & Mean & Std. Dev. \\
\hline \multirow{3}{*}{ Accented } & U-I & 118 & 4.12 & .73 \\
\cline { 2 - 5 } & P-I & 116 & 4.04 & .74 \\
\cline { 2 - 5 } & P-M & 113 & 4.07 & .81 \\
\hline \multirow{3}{*}{ Unaccented } & U-I & 108 & 3.92 & .75 \\
\cline { 2 - 5 } & P-I & 109 & 4.01 & .73 \\
\cline { 2 - 5 } & P-M & 117 & 3.96 & .80 \\
\hline
\end{tabular}

The difference with regards to F2 values between \#VC and \#CV sequences (i.e. where [a] was preceded by a consonant) was not as striking as regarding F1: significant contrast was observed only between accented utterance-initial items ( $\mathrm{p}=.044)$, illustrated in Figure 4. Therefore, consonantal onsets affected vowel height to a greater extent than vowel advancement.

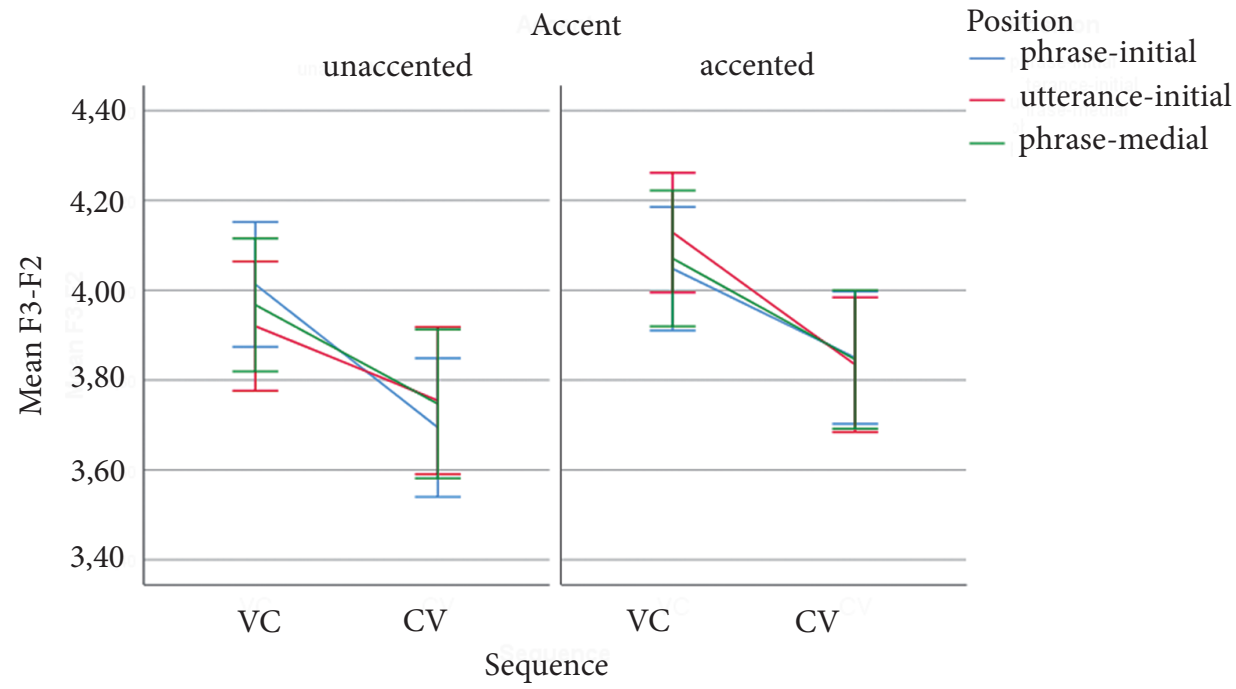

Error bars: $95 \% \mathrm{Cl}$

Figure 4. Comparisons of F2 values (in Bark, F3-F2) of the vowel [a] between the two sequences (\#VC vs. \#CV), sorted for accentedness and prosodic position

The statistical model included the interactions between the Prosodic Position*Accent and speech rate as fixed factors and with Speaker and Item as random factors. Notice that we did not include glottalisation as an additional predictor, as it is more likely to interact with vowel height than with vowel advancement. The analysis showed no statistically significant effects of prosodic position on the phonetic realisation of F2 for [a], as detailed in Table 175. 
Table 17. The summary of the Generalised Mixed Model analysis of the effects of position on the F2 (in Bark, F3-F2) of the vowel [a] in the \#VC sequence (pairwise comparisons)

\begin{tabular}{|c|c|c|c|c|c|}
\hline Accent & Position & Contrast estimate & Std. Error & $\mathbf{t}$ & Sig. \\
\hline \multirow{3}{*}{ Accented } & U-I vs. P-I & .108 & .129 & .831 & .406 \\
\cline { 2 - 6 } & U-I vs. P-M & .092 & .129 & .715 & .475 \\
\cline { 2 - 6 } & P-I vs. P-M & .016 & .126 & .124 & .901 \\
\hline \multirow{3}{*}{ Unaccented } & U-I vs. P-I & .059 & .133 & .446 & .656 \\
\cline { 2 - 6 } & U-I vs. P-M & .092 & .136 & .676 & .499 \\
\cline { 2 - 7 } & P-I vs. P-M & .032 & .137 & .237 & .813 \\
\hline
\end{tabular}

\section{Discussion}

The results of the study of the effects of prosody on F1 and F2 (in Bark, F1- $f_{0}$ and F3-F2 respectively) of the three Polish vowels $[a, \varepsilon, \dot{i}]$ may be summarised as follows. As far as F1 is concerned, it was generally higher in the accented condition across all vowels but [i]. It was also higher for phrase-medial items across the board, which means that the lack of a prosodic boundary preceding the vowel made the vowel susceptible to lowering. On the whole, no significant contrast with respect to F1 was found between utterance-initial and phrase-initial vowels. Contrasts, when present, were minimal and subject to much variation across the accentual conditions and across the vowels.

When it comes to height differences between [a] in \#VC and \#CV sequences, the vowel was lower in the former case, with higher F1 values. This is to be expected, as consonants have been described as affecting the height of vowels that they precede (cf. Stevens and House 1963; Hillenbrand et al. 2000 for general discussion on the effects of consonantal context). Similarly to \#CV sequences, in the absolute-initial position, the highest F1 was found for phrasemedial tokens. Very small differences between utterance-initial and phraseinitial items were observed. The presence or absence of a full glottal stop or glottalisation effects on the quality of the vowel had no bearing on the effects of prosodic position as no contrasts were found.

Turning to F2, by and large no effects of position were found in either \#VC or \#CV sequences. In general, F2 was higher in the accented condition for all three vowels, which means that vowels in this condition tended to be slightly more back. Interestingly, no difference with respect to F2 values for the vowel [a] was found between \#VC and \#CV, in contrast to what was observed for F1. Thus, the preceding consonant had no effect on the advancement of the vowel in any of the prosodic positions.

Figure 5 illustrates a scatter plot with both F1 $\left(\mathrm{F} 1-f_{0}\right)$ and F2 (F3-F2) plotted together, sorted for vowel and prosodic position for \#CV sequences. A visual 
inspection reveals that the differences between positions across all three vowels seem to be minute.

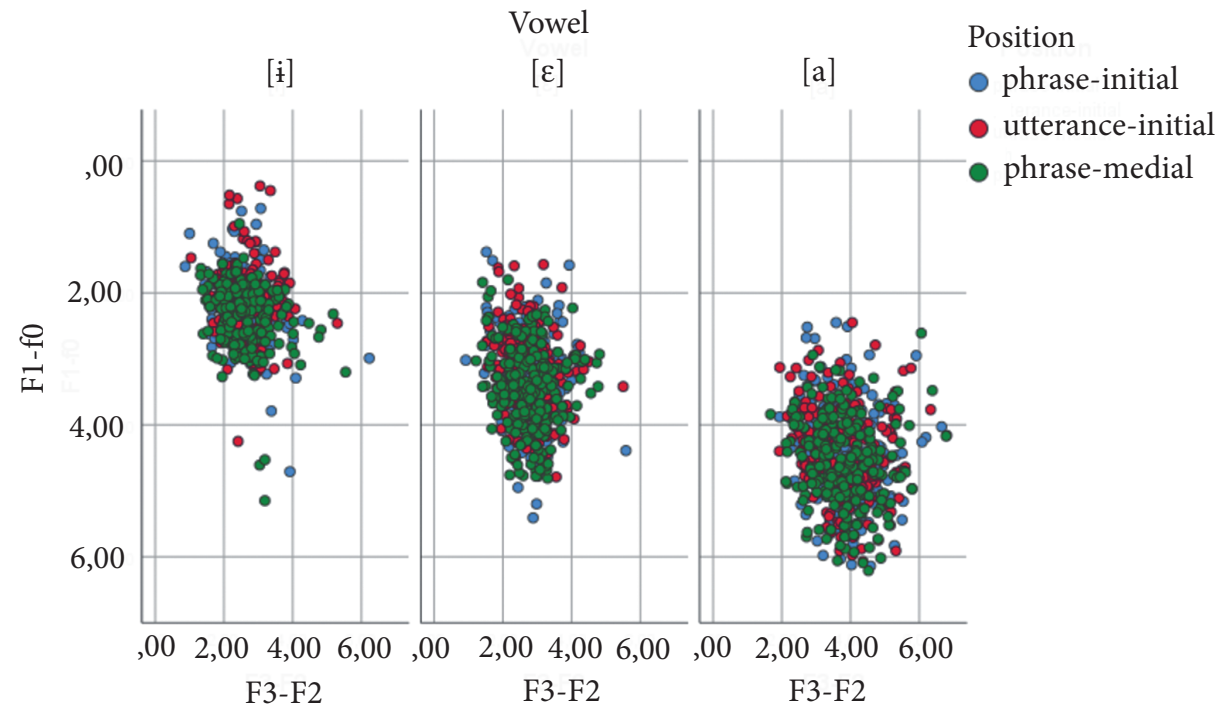

Figure 5. Scatter plots showing vowel dispersion in \#CV sequences, sorted for position

Similarly, a scatter plot with both F1 $\left(\mathrm{F} 1-f_{0}\right)$ and F2 (F3-F2) plotted together, sorted for prosodic position for the vowel [a] in \# $\mathrm{VC}$ sequences is presented in Figure 6 . Notice that only a few individual outliers are visible, with most productions grouping together.

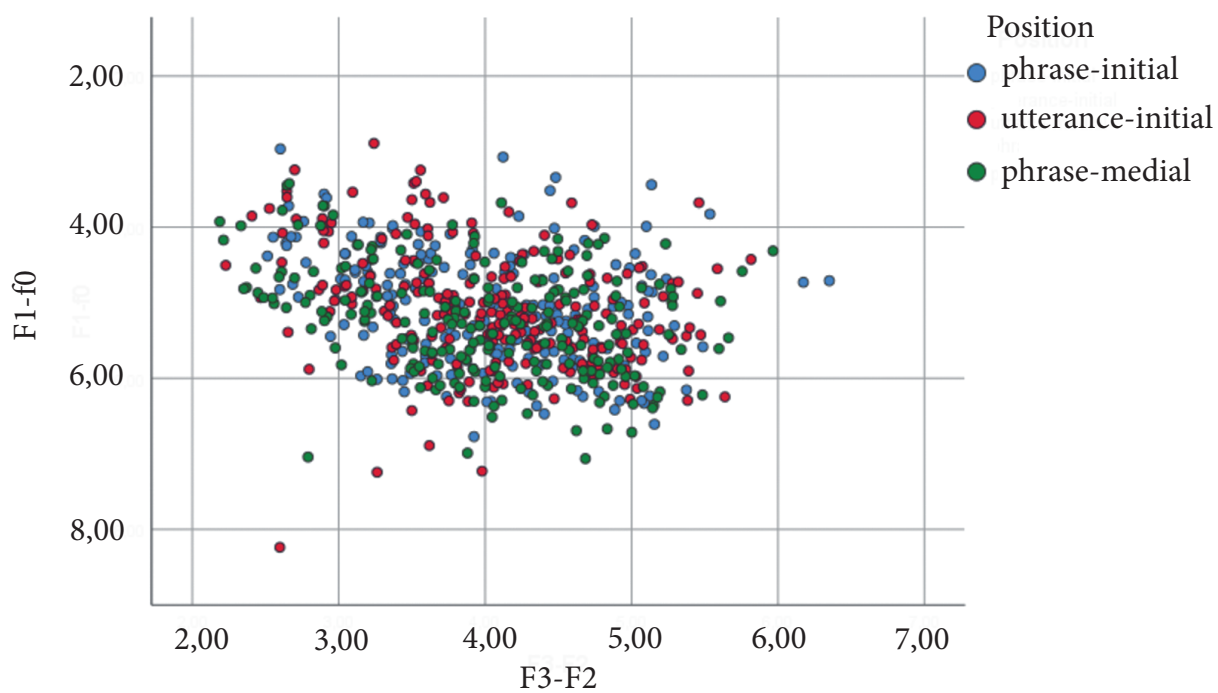

Figure 6. Scatter plot of the vowel [a] in \#VC sequences, sorted for position 
It is worth noting that one more additional analysis was conducted, with vowel duration as the dependent variable, Prosodic Position ${ }^{*}$ Vowel $^{*}$ Accent as the fixed factors and Speaker and Item as random factors, for both \#VC and \#CV sequences. No significant effects of position were found, for which reason we did not describe them in detail in the present paper.

What we can see is that Polish displays very little effects of prosodic position on the phonetic details of the three front vowels described here. The contrasts, when found, are minute and rather inconclusive, as no clear pattern seems to be emerging. These data go in line with previous studies done on Polish, where very small effects of prosodic position on the phonetic realisation of voiceless and voiced stops were found (Wojtkowiak and Schwartz 2019). Combined, the two studies suggest that a traditional Prosodic Hierarchy may not be applicable in Polish, and that we may be in need of an alternative explanation of the origins of prosodic domains in the language. One such proposal is made by Schwartz (2016), who suggests that prosodic domains in Polish are formed by a mechanism of adjunction, which does not produce large hierarchical structures, and by which dramatic effects of prosody on segmental phonetics should not be expected. Further research is therefore warranted to thoroughly investigate the predictions of competing models of prosodic structure.

\section{Abbreviations}

- U-I: utterance-initial

- P-I: phrase-initial

- P-M: phrase-medial

- \#VC: a sequence of a prosodic boundary, a vowel, and a consonant

- \#CV: a sequence of a prosodic boundary, a consonant, and a vowel

\section{References}

Beckman Mary E., Pierrehumbert Janet B. (1986). Intonational structure in Japanese and English. Phonology Yearbook 3, 255-309. DOI: https://doi.org/10.1017/ S095267570000066X

Benguerel André-Pierre, Hirose Hajime, Sawashima Masayuki, Ushijima Tatsujiro (1977). Velar coarticulation in French: An electromyographic study. Journal of Phonetics 5(2), 159-167. DOI: https://doi.org/10.1016/S0095-4470(19)31126-X

Boersma Paul, Weenink David (2019). Praat: Doing phonetics by computer [Computer software]. Version 6.0.46 [URL: http://praat.org; accessed January 22, 2019].

Brunner Jana, Żygis Marzena (2011). Why do glottal stops and low vowels like each other? Proceedings of the $17^{\text {th }}$ ICPhS in Hong Kong, 376-379. 
Chistovich, Ludmilla A., Lublinskaya Valentina V. (1979). The 'center of gravity' effect in vowel spectra and critical distance between the formants: Psychoacoustical study of the perception of vowel-like stimuli. Hearing Research 1(3), 185-195.

CHo Taehong, Jun Sun-Ah (2000). Domain-initial strengthening as featural enhancement: Aerodynamic evidence from Korean. Chicago Linguistics Society 36, 31-44. DOI: https://doi.org/10.1121/1.1861893

Cho Taehong, Keating Patricia A. (2001). Articulatory and acoustic studies of domain-initial strengthening in Korean. Journal of Phonetics 29(2), 155-190. DOI: https://doi.org/10.1006/jpho.2001.0131

Сно Taehong, Keating Patricia A. (2009). Effects of initial position versus prominence in English. Jounal of Phonetics 37(4), 466-485. DOI: https://doi.org/10.1016/j. wocn.2009.08.001

Cho Taehong, McQueen James M. (2005). Prosodic influences on consonant production in Dutch: Effects of prosodic boundaries, phrasal accent and lexical stress. Journal of Phonetics 33(2), 121-157. DOI: https://doi.org/10.1016/j.wocn.2005.01.001

Cho Taehong (2011). Laboratory phonology. In Nancy C. Kula, Bert Botma, Kunira Nasukawa (eds.), The Continuum Companion to Phonology, 343-368. London/ New York: Continuum.

CHOI Hansook (2003). Prosody-induced acoustic variation in English stop consonants. Proceedings of the $15^{\text {th }}$ ICPhS in Barcelona, 2662-2664.

CoHen Jacob (1968). Weighted kappa: nominal scale agreement with provision for scaled disagreement or partial credit. Psychological Bulletin 70(4), 213-220. DOI: https://doi.org/10.1037/h0026256

Cole Jennifer S., Heejin Kim, Choi Hansook, Hasegawa-Johnson Mark A. (2007). Prosodic effects on acoustic cues to stop voicing and place of articulation: Evidence from radio news speech. Journal of Phonetics 35(2), 180-209. DOI: https:// doi.org/10.1016/j.wocn.2006.03.004

DukIEWICZ Leokadia, SAWICKA Irena (1995). Gramatyka współczesnego języka polskiego - fonetyka i fonologia. Kraków: Wydawnictwo Instytutu Języka Polskiego PAN.

Fougeron Cécile, Keating Patricia A. (1997). Articulatory strengthening at edges of prosodic domains. Journal of the Acoustical Society of America 101(6), 3728-3740. DOI: https://doi.org/10.1121/1.418332

Fougeron Cécile (2001). Articulatory properties of initial segments in several prosodic constituents in French. Journal of Phonetics 29(2), 109-135. DOI: https://doi. org/10.1006/jpho.2000.0114

Gendrot Cédric, Gerdes Kim, AddA-Decker Martine (2011). Impact of prosodic position on vocalic space in French and German. Proceedings of the $17^{\text {th }} \mathrm{ICPhS}$ in Hong Kong, 731-734.

Georgeton Laurianne, Fougeron Cécile (2014). Domain-initial strengthening on French vowels and phonological contrasts: Evidence from lip articulation and spectral variation. Journal of Phonetics 44, 83-95. DOI: https://doi.org/10.1016/j. wocn.2014.02.006

Guitard-Ivent Fanny, Chignoli Gabriele, Fougeron Cécile, Georgeton Laurianne (2019). Are IP initial vowels acoustically more distinct? Results from LDA and CNN classifications. Interspeech, 1746-1750. DOI: https://doi.org/10.21437/ Interspeech.2019-2153 
Gussmann Edmund (2007). The Phonology of Polish. Oxford: Oxford University Press. HALlgren Kevin A. (2012). Computing inter-rater reliability for observational data: An overview and tutorial. Tutororials in Quantitative Methods for Psychology 8(1), 23-34.

Hayes Bruce (1989). The prosodic hierarchy in meter. In Paul KIPARsky, Gilbert YouMANs (eds.), Rhythm and Meter, 201-260. Orlando: Academic Press. DOI: https:// doi.org/10.1016/B978-0-12-409340-9.50013-9

Hillenbrand James M., Clark Michael J., Nearey Terrance M. (2000). Effects of consonant environment on vowel formant patterns. Journal of the Acoustical Society of America 109(2), 748-763.

Hoemeke, Kathryn A., Dienl, Randy L. (1994). Perception of vowel height: The role of F1-F0 distance. Journal of the Acoustical Society of America 96(2), 661-674. DOI: https://doi.org/10.1121/1.410305

IBM Corporation (2017). IBM SPSS Statistics for Windows, Version 25.0. Armonk/ New York: IBM Corp.

Jun Sun-Ah (1993). The Phonetics and Phonology of Korean Prosody. PhD dissertation, Ohio State Univeristy.

Keating, Patricia A. (1984). Phonetic and phonological representation of stop voicing. Language 60(2), 286-319. DOI: https://doi.org/10.2307/413642

KIM, Sahyang, CHо Taehong (2011). Effects of prosodic boundary versus accent in the articulation of English /æ/ in \#VC and \#CVC. Proceedings of the $17^{\text {th }} I C P h S$ in Hong Kong.

Kuzla Claudia, Ernestus Mirjam (2011). Prosodic conditioning of phonetic detail in German plosives. Journal of Phonetics 39(2), 143-155. DOI: https://doi. org/10.1016/j.wocn.2011.01.001

LANDIs J. Richard, Косн Gary G. (1977). The measurement of observer agreement for categorical data. Biometrics, 33(1), 159-174. DOI: https://doi.org/10.2307/2529310

LEE Eun-Kyung (2007). Acoustic effects of prosodic phrasing on domain-initial vowels in Korean. Proceedings of the $16^{\text {th }}$ ICPhS in Saarbrücken, 1141-1144.

Lehnert Le-Houiller Heike, McDonough Joyce, McAleavey Stephen (2010). Prosodic strengthening in American English domain-initial vowels. Speech Prosody $100082,1-4$.

Malisz Zofia, Żygis Marzena, Pompino-Marschall Bernd (2013). Rhytmic structure effects on glottalisation: A study of different speech styles in Polish and German. Laboratory Phonology 4(1), 119-158.

Nespor Marina, Vogel Irene (1986). Prosodic Phonology. Dordrecht: Foris Publications.

Pompino-Marschall Bernd, Żygis Marzena (2011). Glottal marking of vowel-initial words in German. Proceedings of the $17^{\text {th }}$ ICPhS in Hong Kong, 1626-1629.

Przedlacka Joanna, Ashby Michael G. (2011). Acoustic correlates of glottal articulations in Southern British English. Proceedings of the $17^{\text {th }}$ ICPhS in Hong Kong.

Redi Laura, Shattuck-Hufnagel Stefanie (2001). Variation in the realization of glottalization in normal speakers. Journal of Phonetics 19(4), 407-429. DOI: https:// doi.org/10.1006/jpho.2001.0145

Schiering René, Bickel Balthasar, Hildebrandt Kristine A. (2010). The prosodic words is not universal but emergent. Journal of Linguistics 46(3), 657-709. DOI: https://doi.org/10.1017/S0022226710000216 
SchwARTz Geoffrey (2012). Initial glottalization and final devoicing in Polish. Research in Language 10(2), 159-171. DOI: http://doi.org/10.2478/v10015-011-0044-7

Schwartz Geoffrey (2013). Vowel hiatus at Polish word boundaries: Phonetic realization and phonological implications. Poznań Studies in Contemporary Linguistics 49(4), 557-585. DOI: https://doi.org/10.1515/psicl-2013-0021

Schwartz Geoffrey (2016). On the evolution of prosodic boundaries: Parameter settings for Polish and English. Lingua 171, 37-73. DOI: https://doi.org/10.1016/j. lingua.2015.11.005

SELKIRK Elisabeth O. (1986). On derived domains in sentence phonology. Phonology Yearbook 3, 371-405. DOI: https://doi.org/10.1017/S0952675700000695

Shattuck-Hufnagel Stefanie, Turk Alice (1996). A prosody tutorial for investigators of auditory sentence processing. Journal of Psycholinguistic Research 25, $193-$ 247. DOI: https://doi.org/10.1007/BF01708572

Stevens Kenneth N., House Arthur S. (1963). Perturbation of vowel articulations by consonantal context: An acoustical study. Journal of Speech and Hearing Research 6(2), 111-128. DOI: https://doi.org/10.1044/jshr.0602.111

Syrdal Ann K., Gopal Hundrai S. (1986). A perceptual model of vowel recognition based on the auditory representation of American English Vowels. Journal of the Acoustical Society of America 79(4), 1086-1100. DOI: https://doi.org/10.1121/ 1.393381

Tabain Marija, Perrier Pascal (2005). Articulation and acoustics of /i/ in preboundary position in French. Journal of Phonetics 33(1), 77-100. DOI: https://doi. org/10.1016/j.wocn.2004.04.003

Tabain Marija, Perrier Pascal (2007). An articulatory and acoustic study of /u/ in preboundary position in French: The interaction of compensatory articulation, neutralization avoidance and featural enhancement. Journal of Phonetics 35(2), 135-161. DOI: https://doi.org/10.1016/j.wocn.2006.05.001

VAISsIÈre Jacqueline (1988). Prediction of velum movement from phonological specifications. Phonetica 45(2-4), 122-139. DOI: https://doi.org/10.1159/000261822

WEISMER, Gary (1979). Sensitivity of voice onset (VOT) measures to certain segmental features in speech production. Journal of Phonetics 7(2), 194-204. DOI: https:// doi.org/10.1016/S0095-4470(19)31041-1

Wojtкоwiak, Ewelina, Schwartz Geoffrey (2019). Prosody-segment interaction in the acoustics of Polish plosives. Proceedings of the $19^{\text {th }}$ ICPhS in Melbourne, 32853289 .

Ewelina Wojtkowiak

Wydział Anglistyki

Uniwersytet im. Adama Mickiewicza w Poznaniu

ul. Grunwaldzka 660-780 Poznań

ewelina.wojtkowiak(at)amu.edu.pl 